\title{
НЕСТАЦІОНАРНІ СТРАТЕГІЇ У ЗАДАЧІ РОЗПОДІЛУ РЕСУРСІВ ІТ ПРОЕКТУ
}

\begin{abstract}
Анотація: У даній статті викладено підхід до розподілу трудових ресурсів IT проекту на основі вибору нестаціонарної змішаної стратегії. Надано імітаційну модель дослідження вірогідного виконання проекту в умовах дії фактору новизни виконуваних робіт, змін зрілості команди та динаміки ризиків. Вирішено задачу оптимізації нестаціонарної змішаної стратегії.

Ключові слова: імітаційна модель, трудові ресурси, IT проект, динаміка ризиків
\end{abstract}

\section{Вступ}

Нестаціонарність середовища реалізації цілей інноваційних проектів закладена в самій природі проектів розвитку IT компаній. Це припускає високу міру свободи діяльності менеджера в застосуванні стратегій, що кардинально відрізняються. Здатність компанії мобілізовувати і використовувати свої нематеріальні активи, стає все більш значущим чинником. У такій обстановці використання і стимулювання креативного потенціалу команди в моделі раціонального ухвалення рішень про зміни пов'язане або із створенням образів майбутнього - цільових станів (управління по цілях), або з образами процесів, моделями поведінки (управління по інструкціях). У процесі реалізації змін у самій компанії змінюеться і розвиваеться і сама команда проекту. На початку виконання проекту лідер команди застосовує більш автократичний стиль управління в умовах формування команди для роз'яснення цілей, задач, процедур та розподілу відповідальності та ролей. Далі стиль керівництва стае більш наставницьким, делегуючим, та демократичним а процеси командної роботи більш досконалими. Цей фактор впливае на перерозподіл ефективності стратегій що залучаються.

Дослідження [3] також показують зміну вірогідності та наслідків ризиків на різних фразах розвитку проекту, яку теж треба брати до уваги при визначенні оптимальних стратегій управління.

Усе це визначає доцільність визначення нестаціонарних змішаних стратегій управління та розподілу ресурсів проекту у відповідності із фазами розвитку проекту.

\section{Постановка задачі}

Розглянемо задачу побудови оптимальної нестаціонарної змішаної стратегії виконання проекту розвитку IT компанії за критерієм інтегральної набутої цінності проекту. Цей показник подамо у вигляді зваженої суми заявлених цінностей проекту.

Серед запропонованих експертами стратегій розміщення ресурсів необхідно віднайти таку послідовність застосування змішаних стратегій, якою можна користуватися при виборі конкретної стратегії в моменти

(c) О.В. Гриша, 2011 
конфрлікту за ресурси, щоб отримати мінімальний час виконання проекту $T: p(T>\bar{T}) \leqslant 0,95 \rightarrow \min$. Ця послідовність залежить від зменшення новизни робіт проекту [1] у процесі його виконання, від розвитку команди і процесів управління та від динаміки ризиків $R$ і відповідно чутливості до них наслідків обраних стратегій $S . M: R \times S \rightarrow K$ - матриця чутливості результатів застосування стратегій від впливу визначених ризиків проекту задається відповідним коефіцієнтом $k \in K$ погіршення часу виконання при виборі даної стратегії у даний час. Припустимо, що випадкова величина реалізації ризиків проекту має $\beta$ - розподіл з різними коефіціентами для різних ризиків.

Нехай розподіл випадкової величини реалізації ризиків $R$ задано щільністю вірогідності $f_{R}(r)$, що має вигляд $f_{R}(r)=\frac{1}{B(\alpha, \beta)} r^{\alpha-1}(1-r)^{\beta-1}$, де $\alpha, \beta>0$ - довільні фіксовані параметри, свої для кожного типу ризику. $B(\alpha, \beta)-\beta$ функція, тобто $R \sim B(\alpha, \beta)$ має місце для усіх ризиків.

Оскільки експертні оцінки є наближеними і процес створення IT технологій має ще багато факторів невизначеності, пошук вирішення задачі слід шукати серед методів наближеної оптимізації. Ця задача може бути віднесена до класу задач дискретної математики.

\section{Вирішення задачі}

Для вирішення поставленої задачі пропонуеться модифікація алгоритму методу вектору спаду [2]. Множина допустимих рішень $(X)$ методу Сергієнка повинна бути конечною або злічимою. Хоча в даній задачі $X$ має незліченну множину рішень, як значень вірогідності використання стратегій для кожної з фаз розвитку проекту, проте можна ввести припущення про крок мінімально відчутної зміни вірогідності. У якості вектору спаду пропонується напрямок між рішенням з меншим значенням цільової фрункції та іншим припустимим рішенням. У зв'язку з тим, що у даній постановці не існує формальної математичної залежності між рішенням $x \in X$ та значенням функції $f(x)$, використано імітаційне моделювання для встановлення значення цільової функції. На рисунку 1 подано схему імітаційної моделі виконання проекту.

Розглянемо наступну задачу:

$$
\min _{x \in X} f(x),
$$

де $X=\left\{\overline{p^{1}}, \overline{p^{2}}, \bar{z}\right\}$ - безкінечний простір допустимих рішень задачі; $f(x)$ визначена у просторі цільова функція $T=f(x)$ - час виконання проекту, алгоритмічна залежність - значення функції вираховуеться шляхом імітаційного моделювання ;

$S^{1}$ - множина стратегій формування поточного фронту робіт при конфрлікті за ресурси;

$S^{2}$ - множина стратегій пріоритетного розміщення робіт фрронту в черзі за ресурсами;

$Z$ - множина фраз виконання проекту;

$\overline{p_{i}^{1}}=\left(p\left(s_{1 i}^{1}\right), p\left(s_{2 i}^{1}\right), \ldots p\left(s_{j i}^{1}\right), \ldots p\left(s_{n i}^{1}\right)\right)-i$-та змішана стратегія типу $S^{1}$; 
$\overline{p_{i}^{2}}=\left(p\left(s_{1 i}^{2}\right), p\left(s_{2 i}^{2}\right), \ldots p\left(s_{j i}^{2}\right), \ldots p\left(s_{n i}^{2}\right)\right)-i$-та змішана стратегія типу $S^{2}$;

$z_{i} \in Z-i$-та фаза проекту з повної множини $Z$.

$x_{i}=\left(\overline{p_{i}^{1}}, \overline{p_{i}^{2}}, z_{i}\right)-i$-те рішення $x_{i} \in X$.

Пропонуеться наступний алгоритм пошуку оптимального варіанту вирішення задачі :

begin

$x:=\operatorname{random}[0,1] ; x 1:=\operatorname{random}[0,1] ;$ \{деякі початкові варіанти рішення $x, x 1\}$

\{Варіант рішення - це розігрування порядкових номерів стратегій для обох груп

$$
p\left(s_{1}^{1}\right)=\operatorname{random}[0,1], \quad p\left(s_{i}^{1}\right)=\operatorname{random}\left[0,1-\sum_{i 1=\overline{1, i-1}} p\left(s_{i 1}^{1}\right)\right],
$$

$\left.p\left(s_{1}^{2}\right)=\operatorname{random}[0,1], \quad p\left(s_{i}^{2}\right)=\operatorname{random}\left[0,1-\sum_{i 1=\overline{1, i-1}} p\left(s_{i 1}^{2}\right)\right]\right\} ;$

$T=T^{0}$; \{час виконання проекту по даним Case - засобу підготовки проекту $\}$;

$l:=0$; номер глобальної ітерації $\} ;$ \{точність обрахунку\};

$\lambda$ \{розмір кроку у напрямок тенденції до локального мінімуму\};

$f(x):=T ;$;вираховуеться шляхом підрахунку статистичних даних серії імітаційного моделювання \};

$t[i]\{$ Масив накопичення результатів $\}$;

$m\{$ потужність множини перевірки результату\};

$m 1$ \{максимальна кількість випробувань \};

$z m$ \{загальна кількість фаз проекту \};

$t[0,0]:=T ; z:=1$;

while $\left(\max _{i=[l-m, l-1]}|t[l, z]-t[i, z]|>\xi \& l<m 1\right) !(l<m)$ do \{ не досягнуто умови виходу $\}$

begin

while $(z \leqslant z m)$ do \{ не усі фози виконано \}

begin

begin

if $(f(x 1, z)<f(x, z))$ then do

begin

$y:=x 1 ; x 1:=x ; x:=y$;

end;

$y:=$ null;

while $(|f(x, z)-f(y, z)|>\xi ! f(x, z)<f(y, z) ! y:=n u l l)$ do\{не досягнуто локального мінімуму

begin

$y:=x+\lambda(x 1-x) ;\{$ рух уздовж прямої $x->x 1\}$

$f(y, z):=T$

if $(f(y, z)<f(x, z))$ then do

begin

$(f(x, z)=f(y, z)) ; y:=n u l l ;$ 
end;

end;

$\mathrm{x} 1:=\operatorname{random}[0,1]$;

$f(x 1, z):=:=T$;

$t[l, z]=f(x, z) ; l:=l+1$;

end;

Вивід найкращого значення для фрази та номеру фрази проекту;

$$
z:=z+1:
$$

end;

end.

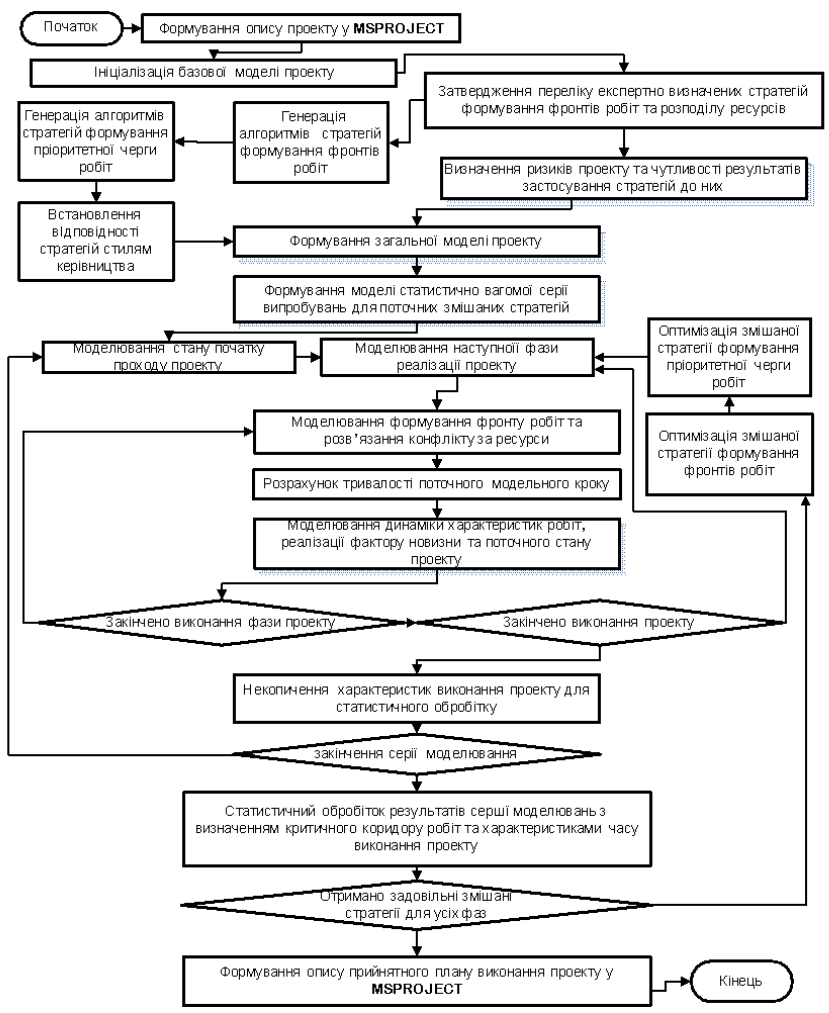

Рис. 1 - Схема імітаційної моделі виконання проекту

\section{Висновки}

Формування стратегій управління трудовими ресурсами IT проектів залежить не тільки від потенціалу команди і ризику, спричиненому новизною робіт, але й від динаміки інших ризиків виконання проекту в 
нестаціонарному середовищі. Вибір стратегій повинен базуватися також в залежності від фазах життевого циклу проекту, ситуаційний вибір з множини підтверджених модельним експериментом ефективних стратегій повинен здійснюватися з урахуванням зрілості результату проекту. Така змішана стратегія не повинна бути одною на всьому протязі досягнення поставлених цілей і може бути визначена за допомогою вирішення задачі оптимізації над даними імітаційної моделі.

Пропонований підхід до управління трудовим потенціалом IT проекту показуе доцільність і можливість визначення оптимальної нестаціонарної змішаної стратегії на основі запропонованої імітаційної моделі виконання IT проекту в нестаціонарних умовах.

\section{Література}

1. Гриша О.В. Методика управління креативними IT проектами з врахуванням ризику інверсного просування. // Дніпропетровськ: Системні технології. Регіональний міжвузівський збірник наукових праць. - 1. - 2007. - С. 117-129.

2. Сергиенко И.В. Задачи дискретной оптимизации / В.П. Шило. - К.: Наук. думка, 2003. - 259c.

3. Уокер Ройс. Управление проектами по созданию программного обеспечения.- М.:Издательство “Лорри”, 2002, -432с.

Отримано 12.03.2011 p. 